\title{
Liter per Mole
}

National Cancer Institute

\section{Source}

National Cancer Institute. Liter per Mole. NCI Thesaurus. Code C85680.

Liters per mole. 